\title{
A poststernotomiás sebfertőzések kezelési sikertelenségének prediktív faktorai
}

\author{
Rashed Aref dr. ${ }^{1}$ - Gombocz Károly dr. ${ }^{1}$ - Frenyó Magdolna dr. ${ }^{1}$ \\ Alotti Nasri dr. ${ }^{1}$ - Verzár Zsófia dr. ${ }^{2}$ \\ 'Zala Megyei Szent Rafael Kórház, Szívsebészeti Osztály, Zalaegerszeg \\ ${ }^{2}$ Pécsi Tudományegyetem, Általános Orvostudományi Kar, Sürgősségi Orvostani Tanszék, \\ Sürgősségi Betegellátó Osztály, Pécs
}

\begin{abstract}
Bevezetés és célkitüzés: A szívműtétek során a sternotomia utáni sebfertôzések komoly aggodalomra adnak okot, ugyanis befolyásolják a morbiditást, a mortalitást és a kórházi költségeket is. A rekonstrukció sikertelensége tovább növeli ezeket a kockázatokat, mert a sebfertőzések súlyos szövődményekkel járhatnak. Azoknak a tényezőknek a feltárása, amelyek jelentősen befolyásolhatják a sebészi kezelés sikerességét.

Módszer: Egycentrumos retrospektív vizsgálat történt egymást követő 3177, medián sternotomián átesett beteg adataiból. A poststernotomiás sebfertőzések diagnózisa 60 betegnél (1,9\%) volt megállapítható. Az adatok alapos elemzésével olyan tényezőket kerestünk, amelyek jelentősen hozzájárulhatnak a sebészi rekonstrukció sikertelenségéhez. Eredmények: A diagnózis késői felállítása mellett a pozitív sebváladék mikrobiológiai vizsgálata, a radikális sebészi rekonstrukció és a perifériás érbetegség jelentősen befolyásolja a sebészi kezelés eredményességét. A radikális sebészi rekonstrukció szignifikánsan magasabb arányban járt sikerrel, mint a hagyományos kezelés $(81,8$ vs. 11,1\%), p<0,001. Következtetés: Szükséges azonosítani azokat a tényezőket, amelyek prediktív jelentőséggel bírnak a sebészi kezelés szempontjából, ezek segíthetnek a kezelési algoritmusok fejlesztésében és a sebészi rekonstrukciók sikerességében. Orv Hetil. 2018; 159(14): 566-570.
\end{abstract}

Kulcsszavak: sebészi sebfertőzés, sternotomia, helyreállító sebészi eljárások

\section{Predictive factors for treatment failure of post-sternotomy wound infections}

Introduction and aim: Post-sternotomy wound infection is still a major concern and it affects morbidity, mortality, and hospital costs. Reconstruction failure may further increase these risks with significant financial implications. Method: Here, we attempted to verify some factors that may significantly influence the success of the surgical treatment. We performed a single-center retrospective analysis of data from 3177 consecutive patients who underwent midline sternotomy. The diagnostic signs of post-sternotomy wound infections were observed in 60 patients (1.9\%). These data were thoroughly analyzed.

Results: Beside late diagnosis, the positive microbiological culture of the wounds, radical surgical intervention and peripheral vascular disease were found to significantly contribute to the development of surgical reconstruction failure. Radical surgical reconstruction was associated with a higher success rate $(81.8$ vs. $11.1 \%), \mathrm{p}<0.001$.

Conclusion: Identification of the predictive factors that may lead to treatment failure can assist in developing treatment algorithms and improving the success rates of surgical reconstructions.

Keywords: surgical wound infection, sternotomy, reconstructive surgical process

Rashed A, Gombocz K, Frenyó M, Alotti N, Verzár Zs. [Predictive factors for treatment failure of post-sternotomy wound infections]. Orv Hetil. 2018; 159(14): 566-570.

(Beérkezett: 2017. november 22.; elfogadva: 2017. december 21.) 
A szívmútét utáni szegycsonti fertőzések okozta súlyos szövődmények ellenére sincs széles körben elfogadott algoritmus a poststernotomiás sebfertőzések kezelésére. Ez főként a sebfertőzések vonatkozásában általánosan elfogadott definíció hiányának köszönhető, hiszen a legtöbb definíció epidemiológiai természetû és csak néhány klinikai szempontot tartalmaz, így csak részben segíthet a kezelés folyamatának megszervezésében. Bár egyes munkacsoportok helyi algoritmusokat hoztak létre, ezek viszonylag kisméretú helyi adatokon alapultak, és a sikerességi arányok a sebészi tapasztalatoktól függenek [1]. Hiányoznak még azok a randomizált kontrollált többcentrumos vizsgálatok, amelyek beszámolnának a különböző terápiás módszerek eredményeiról. Így e súlyos szövődmény kezelése továbbra is a sebész tapasztalatától függ. A sebészi rekonstrukció sikertelenségében kulcsfontosságú szerepet játszhatnak a betegekkel kapcsolatos rizikótényező́k, a sebészi tapasztalat, a fertőzött sebek állapota és a kórokozó mikroorganizmus virulenciája. Tanulmányunkban olyan tényezőket vizsgáltunk, amelyek bizonyítottan hozzájárulhatnak a kezelési sikertelenség kialakulásához. Ezeknek a tényezóknek az ismerete vezethet jobb döntési stratégiákhoz e sebek kezelése során.

\section{Módszer}

Osztályunkon 2012. január 1-től 2016. december 31-ig (öt év) 3177 betegnél végeztünk szívmútét során sternotomiát. A vizsgálat során retrospektív analízist végeztünk, a betegek adatait visszamenôlegesen gyújtöttük össze és elemeztük. A összes betegnél azonos és a nemzetközi irányelvek alapján meghatározott perioperatív antibiotikus profilaxist alkalmaztunk ( $2 \mathrm{~g}$ cefazolin az anesztézia bevezetésekor, és 24 óráig folytattuk) [2].

A poststernotomiás sebfertőzés diagnózisát 60 betegnél állítottuk fel a Betegségmegelózési és Ellenőrzési Központ (Centers for Disease Control and Prevention [CDC], Atlanta, GA, USA) kritériumai alapján [3]. Ez az esetek 1,9\%-a volt. A CDC mély sebészi sebfertőzési kritériumait az 1 . táblázat foglalja össze.

Pairolero osztályozása szerint ( $2 / A$ és $2 / B$ táblázat) a fertőzés manifesztációs ideje alapján a sebfertőzést elszenvedett betegeket három alcsoportra osztottuk [4]. I. csoport: a mútét napja és a 6 . posztoperatív nap között (0-6. nap); II. csoport: a mútét utáni 7. és 30. nap között (7-30. nap); és III. csoport: a 30. posztoperatív nap után (a 30. nap után) történt a fertőzés. Az I. csoportba tartozó infekciókat általában még osztályunkon észleltük, míg a II. és a III. csoportba tartozó fertőzések rendszerint már a rehabilitációs osztályokon vagy később voltak észlelhetók. A sebváladék mikrobiológiai vizsgálatát rutinszerúen végeztük, függetlenül a váladék minőségétől (savós vagy purulens). Staphylococcus aureus a bakteriológiai minták 36,6\%-ában, Gram-negatív kórokozók a minták 13,3\%-ában tenyésztek ki. A bakteriológiai minták 5\%-ában polimikrobiális kolonizációt figyeltünk meg.
1. táblázat

\section{Kritériumok}

A sebfertőzés a mútét után 30 napon belül, implantátum esetén l éven belül jelentkezik,

ÉS

a bemetszés által érintett mélyebb szövetekben (fascia, izomszövet) lokalizálódik,

ÉS

az alábbi feltételek közül legalább egynek teljesülnie kell:

a) gennyes váladékozás a seb mélyebb rétegeiből,

b) a mély bemetszés spontán szétválása vagy ennek sebész által való újra megnyitása, vagy a bemetszésből nyert minta tenyésztési vizsgálata pozitív,

ÉS

c) Ha a betegnél az alábbi tünetek közül legalább egy fennáll: $38^{\circ} \mathrm{C}$-nál magasabb láz, helyi fájdalom vagy érzékenység. Negatív tenyésztési eredmény ezt a kritériumot kizárja.

d) A mély bemetszés reoperációja során végzett direkt vizsgálat vagy a szövettani, radiológiai vizsgálat tályogra vagy más egyértelmú fertőzésre utal.

$\mathrm{CDC}=$ Center for Disease Control and Prevention (Atlanta, GA, USA)

2/A táblázat $\mid$ A mély sternalis sebfertőzések Pairolero szerinti osztályozása

\begin{tabular}{ll}
\hline Osztályozás & A posztoperatív sebfertőzés manifesztációs ideje \\
\hline I. típus & Az első posztoperatív héten \\
II. típus & A 2. és a 6. posztoperatív héten \\
III. típus & $\begin{array}{l}\text { A 6. posztoperatív héttől évekig (általában } \\
\text { fisztulák és krónikus osteomyelitis formájában) }\end{array}$ \\
\hline
\end{tabular}

2/B táblázat $\mid$ A vizsgált betegek csoportosítása Pairolero osztályozása szerint

\begin{tabular}{lcc}
\hline I. csoport & $\mathrm{n}=18$ & $30 \%$ \\
II. csoport & $\mathrm{n}=32$ & $53,3 \%$ \\
III. csoport & $\mathrm{n}=10$ & $16,7 \%$ \\
\hline Összesen & $\mathrm{n}=60$ & $100 \%$ \\
\hline
\end{tabular}

A sebváladék mikrobiológiai eredményeit az 1. ábra mutatja.

Több tényezőt elemeztünk, amelyek a sebfertőzések mútéti rekonstrukciója során megjósolhatták a kezelés eredményességét. Megvizsgáltuk a sebfertőzés kialakulásához hozzájáruló rizikótényező́knek (nem, életkor, testtömegindex, cukorbetegség, krónikus obstruktív tüdőbetegség, perifériás érbetegség, a szívmútét típusa és sürgős jellege, arteria thoracica interna használata és a transzfúzió szükségessége), a fertőzés megjelenési időpontjának, a sebészi rekonstrukció típusának és a mikrobiológiai vizsgálatok eredményének hatását a sebészi kezelés sikertelenségére. Vizsgálatunkban a sebészi kezelést sikertelennek ítéltük, ha 1) újabb sebészi beavatkozásra volt szükség, 2) a nyílt sebkezelés folytatása vagy 3) a sebkezelés ideje alatt halál következett be. A fent említett faktorokat azonosítottuk, és a sebészi kezelés sikertelen- 


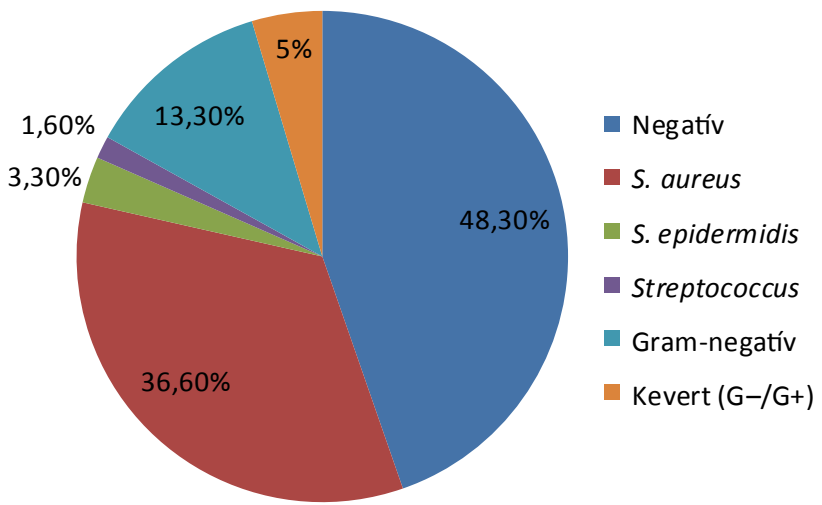

l. ábra A sebváladék-mikrobiológiai vizsgálat eredményeinek összetétetele

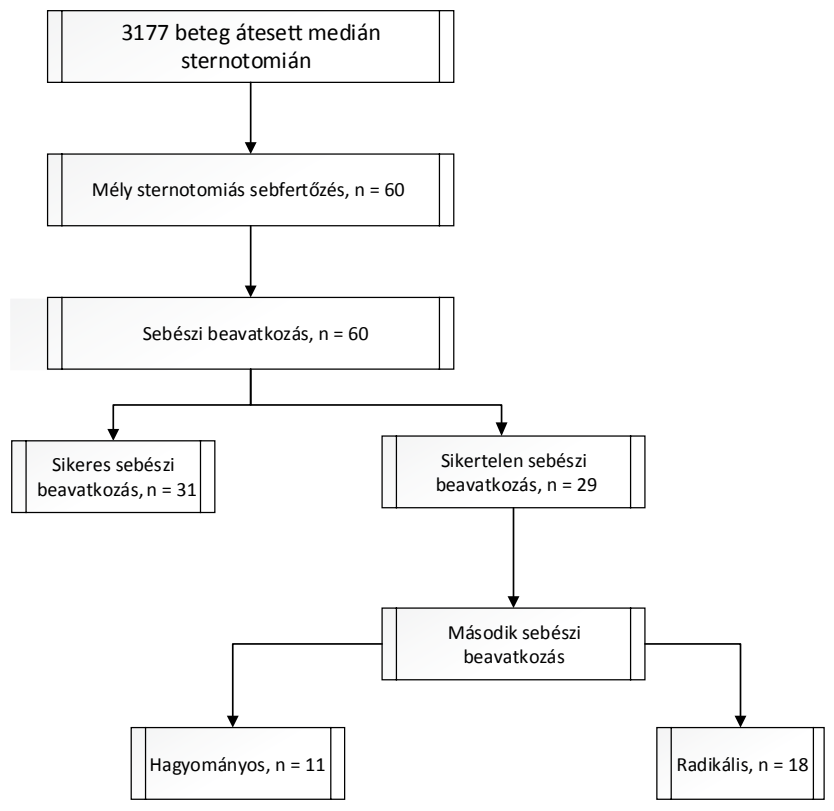

2. ábra

A vizsgált betegek csoportosítása a sebészi beavatkozás jellege
szerint

ségére való hatásukat vizsgáltuk és statisztikailag elemeztük.

Az első sebészi rekonstrukciót minden esetben hagyományos szívsebészeti eljárásokkal végeztük (a sternalis végek újbóli rögzítése drótokkal, szívó-öblítő drenázs, sebzárás Redon-drenázzsal, negatív nyomású sebterápia vagy nyílt sebkezelés). Azoknál a betegeknél, akiknél az első mútéti rekonstrukció sikertelen volt, második rekonstrukciós kísérletet végeztünk $(\mathrm{n}=29)$. A második rekonstrukciós beavatkozáson átesett betegeket két alcsoportba osztottuk a sebészi beavatkozás radikális természete alapján. A radikális sebészi beavatkozások közé tartozott a hemi- vagy teljes sternectomia, a bordák porcos részének reszekciója és a sebzárás egyoldali vagy kétoldali pectoralisizom-lebeny felhasználásával (R-csoport, $\mathrm{n}=11$ ). Tizennyolc betegnél ismételt hagyományos beavatkozás történt (C-csoport, $\mathrm{n}=18$ ) (2. ábra).

\section{Statisztikai analizis}

A statisztikai elemzés során az IBM SPSS Statistics 20-as verzióját használtuk. Az alapadatok összehasonlításához egy khí-négyzet-tesztet és egy Student's t-próbát alkalmaztunk. Ha a variancia homogenitásának feltételezése nem teljesült, akkor a nonparametrikus Mann-Whitneytesztet használtuk. A lineáris asszociáció mérésére Mantel-Haenszel khí-négyzet-próbát alkalmaztunk. Bármely különbség statisztikailag szignifikánsnak tekinthető, ha $\mathrm{p}<0,05$.

\section{Eredmények}

Vizsgálatunkban 60 betegnél $(60 / 3177,1,9 \%)$ diagnosztizáltunk mély sternalis sebfertőzést a CDC-kritériumok alapján. Az első sebészi rekonstrukció sikertelensége 29 esetben fordult elő (48,3\%). A vizsgálatba bevont 60 beteg eloszlása a Pairolero-osztályozás szerint a következőképpen alakult: I. csoport: 18 beteg (30\%); II. csoport: 32 beteg $(53,3 \%)$; és III. csoport: 10 beteg (16,7\%). A sebfertőzés megjelenési ideje szerint a sebészi rekonstrukció sikertelenségét az I. csoport 27,8\%-ában, a II. csoport $53,1 \%$-ában és a III. csoport 70\%-ában figyeltük meg. Azon esetekben, amikor a mütéti rekonstrukció sikertelen volt, a poststernotomiás sebfertőzések később kerültek felfedezésre, mint azokban az esetekben, amikor a kezelés sikeres volt (3. ábra). A sebészi kezelés sikertelensége gyakoribb volt, ha a rekonstrukció idején a sebváladék mikrobiológiai vizsgálata pozitív volt (69,0\% vs. $22,6 \%, p<0,001)$. A seb mikrobiológiai vizsgálatának a sebészi kezelés sikertelenségére gyakorolt hatását a 4. ábrán mutatjuk be. Vizsgálatunkban a leggyakrabban tenyésztett organizmus a Staphylococcus aureus volt.

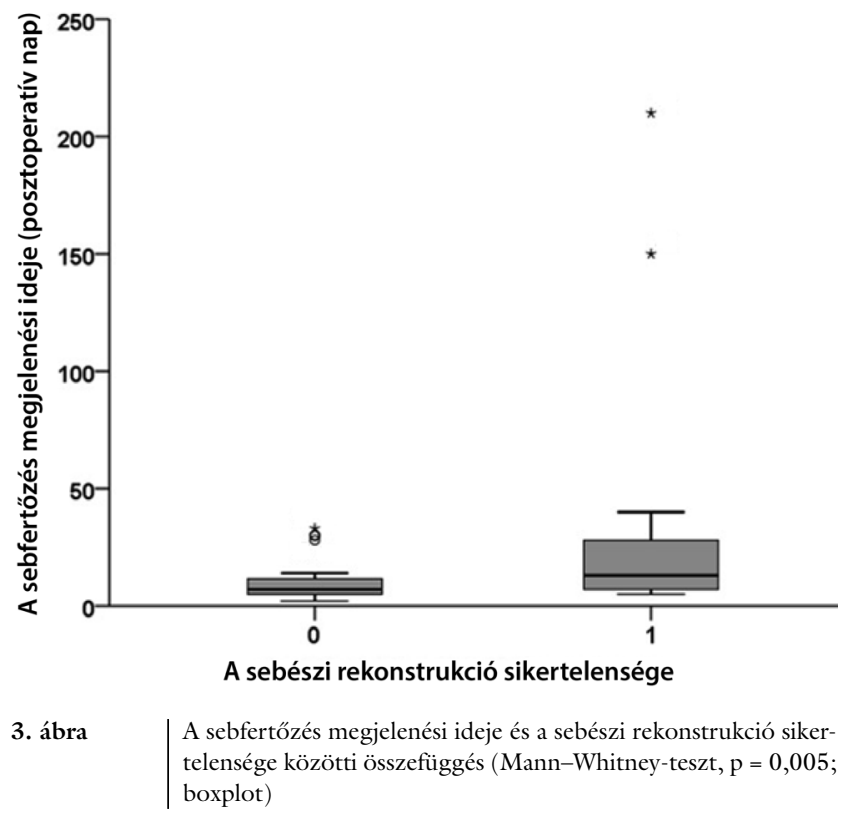




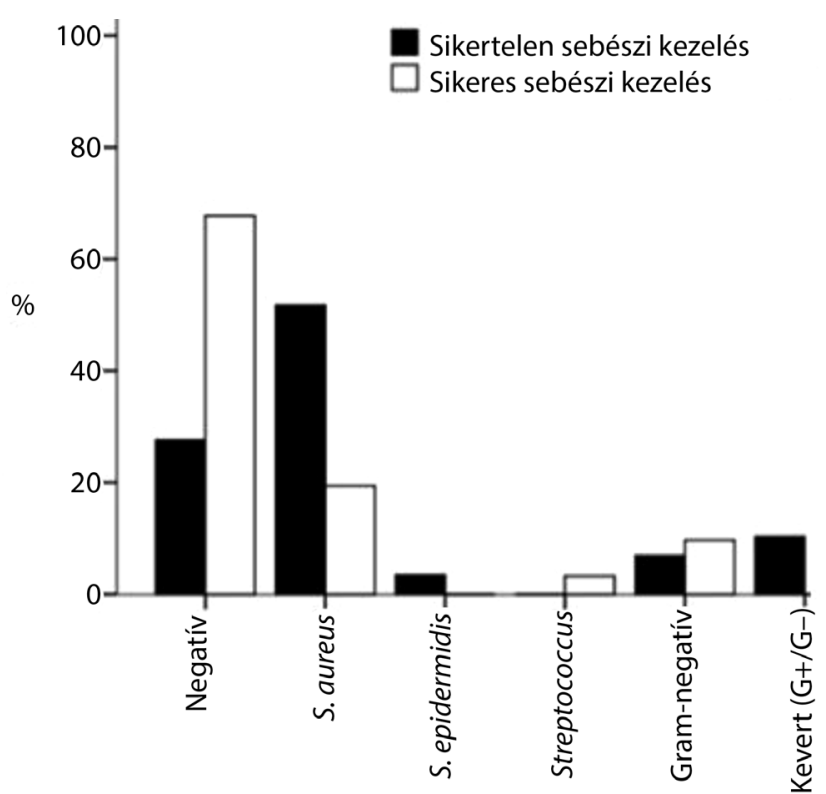

4. ábra

A sikeres és a sikertelen sebészi kezelés eredménye és a sebvála dék-bakteriológia vizsgálati eredménye közti összefüggés $(\mathrm{p}=0,011)$

3. táblázat | Rizikófaktorok és a sebészi rekonstrukció eredménye közötti összefüggés

\begin{tabular}{|c|c|c|c|}
\hline & $\begin{array}{l}\text { Sikertelen első } \\
\text { sebészi kezelés } \\
(\mathrm{n}=29)\end{array}$ & $\begin{array}{c}\text { Sikeres első } \\
\text { sebészi kezelés } \\
(\mathrm{n}=31)\end{array}$ & p-érték \\
\hline Férfi, n (\%) & $19(65 \%)$ & $25(80 \%)$ & 0,185 \\
\hline Kor (év), átlag \pm SD & $63,6 \pm 7,6$ & $64,3 \pm 6,8$ & 0,732 \\
\hline $\begin{array}{l}\text { Elhízás } \\
(\text { BMI>30 kg/m²), } \\
\mathrm{n}(\%)\end{array}$ & $10(34,5)$ & $5(16 \%)$ & 0,101 \\
\hline $\mathrm{DM}, \mathrm{n}(\%)$ & $18(62 \%)$ & $14(45 \%)$ & 0,190 \\
\hline COPD, n (\%) & $15(51 \%)$ & $9(29)$ & 0,073 \\
\hline PVD, n (\%) & $13(44 \%)$ & $3(9,7 \%)$ & 0,002 \\
\hline CABG, n (\%) & $24(82 \%)$ & $25(80 \%)$ & 0,833 \\
\hline LIMA, n (\%) & $20(69 \%)$ & $23(74 \%)$ & 0,653 \\
\hline RIMA, n (\%) & $2(6,9 \%)$ & $3(9,7 \%)$ & 0,697 \\
\hline AVR/AVP, n (\%) & $8(27,6 \%)$ & $8(25,8 \%)$ & 0,876 \\
\hline MVR/MVP, n (\%) & $1(3,4 \%)$ & $1(3,2 \%)$ & 0,962 \\
\hline $\begin{array}{l}\text { Az aorta ascendens } \\
\text { rekonstrukciója }\end{array}$ & $2(6,9 \%)$ & $0(0 \%)$ & 0,137 \\
\hline Akut beavatkozás & $5(17,9 \%)$ & $9(29 \%)$ & 0,134 \\
\hline $\begin{array}{l}\text { Vörösvértest-transz- } \\
\text { fúzió, átlag } \pm S D\end{array}$ & $2,14 \pm 3,4$ & $1,6 \pm 2,1$ & 0,473 \\
\hline
\end{tabular}

AVR/AVP = aortic valve replacement/aortic valve plasty; BMI = (body mass index) testtömegindex; $\mathrm{CABG}=$ coronary artery bypass grafting; $\mathrm{COPD}=$ chronic obstructive pulmonary disease $; \mathrm{DM}=$ diabetes mellitus; LIMA = left internal mammary artery; $\mathrm{MVR} / \mathrm{MVP}=$ mitral valve replacement/mitral valve plasty; PVD = peripheral vascular disease; $\mathrm{RBC}=$ red blood cell; RIMA = right internal mammary artery; SD = (standard deviation) standard eltérés

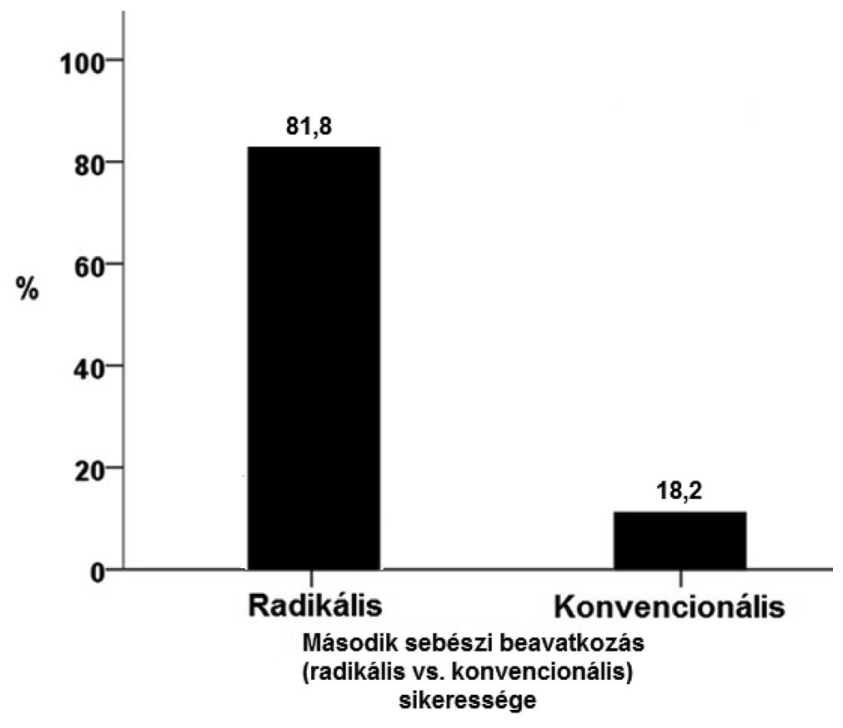

5. ábra $\quad$ A sikeres sebészi kezelés aránya a radikális és a konvencionális sebészi beavatkozásokat követően

A sebészi rekonstrukció sikertelensége akkor is gyakrabban fordult elő, amikor a sternalis végek újbóli rögzítése történt (23 beteg) (65,2\% vs. kontrollcsoport 37,8\%, $\mathrm{p}=0,039)$. Minden sternalis rögzítést drótokkal végeztünk. Öt esetben a Robicsek által alkalmazott hosszanti és haránt sternalis rögzítést végeztük. Az utóbbi csoportban a kezelés sikertelensége 100\% volt. A sebészi rekonstrukció típusa és a sebváladék pozitív mikrobiológiai vizsgálata között lineáris összefüggés $(\mathrm{p}=0,001)$ volt. A vizsgált rizikótényezők közül a perifériás érbetegség az egyetlen olyan faktor, amely negatívan járult hozzá a sebészi rekonstrukció eredményéhez (3. táblázat). Az első sebészi rekonstrukció sikertelensége után végeztünk egy második mütéti rekonstrukciót. A második sebészi beavatkozás radikális volt 11 betegnél és hagyományos 18 betegnél. A radikális sebészi csoportban a rekonstrukció szignifikánsan magasabb arányban járt sikerrel, mint a hagyományos csoportban $(88,1 \%$ vs. $11,1 \%), \mathrm{p}<0,001$ (5. ábra). Retrospektív vizsgálatunkban 5 beteg elhalálozott (12\%). A halálozási arány különbsége a hagyományos és a radikális csoport között szignifikáns volt $(5 / 18$ vs. $0 / 11,27,6 \%$ vs. $0 \%, \mathrm{p}=$ $0,002)$.

\section{Megbeszélés}

A poststernotomiás sebfertőzés ritka, de súlyos szövődmény a medián sternotomián át végzett nyitott szívmütétek után [5]. A sebfertőzést elszenvedett betegeknél nagyobb a halálozási arány, mint azoknál, akiknél sebfertőzés nem volt. A sebészi kezelés sikertelensége negatív pszichogazdasági hatásokkal járhat, és tovább csökkentheti a túlélési arányokat [6]. Nincsenek általánosan elfogadott iránymutatások a poststernotomiás sebfertőzések kezelésére, és nincsenek olyan tényezők, amelyek a terá- 
piás döntéshozatalt irányítanák. Megvizsgáltuk néhány tényező szerepét a sebészi rekonstrukció sikertelenségének kialakulásában. Ezeknek a faktoroknak a megismerése segítheti az azzal foglalkozó sebészeket a kezelési sikertelenség aranyának csökkentésében és a túlélési mutatók javításában. A Pairolero által bejelentett osztályozás a fertőzés manifesztációjának időpontján alapul. Ez a besorolás a fiziológiai sebgyógyulási folyamaton alapszik. Az I. típusú sebek a gyulladásos fázis során jelentkeznek, míg a II. típusú sebek a proliferációs fázisban fordulnak elő, és a III. típusú sebek a remodelling fázisra terjedhetnek. Betegeinket három csoportra osztottuk e fázisok alapján. Vizsgálatunkban megfigyeltük, hogy a kezelés sikertelensége gyakoribb, ha a fertőzés a sebgyógyulás későbbi fázisaiban jelentkezik. A pozitív sebváladék-bakteriológiai minta szerepe a rekonstrukció idején még mindig ellentmondásos $[7,8]$. Vizsgálatunkban azt találtuk, hogy a pozitív bakteriológiai leoltással rendelkező seb esetében jobb eredmények vannak a kiterjesztett radikális sebészi débridement során. Azt találtuk, hogy a pozitív bakteriológiai minták jelentősen hozzájárultak a kezelés sikertelenségéhez.

\section{Következtetés}

Sok rizikótényező ismert, amely hozzájárulhat a szívmütét utáni poststernotomiás sebfertőzés kialakulásához [9, 10]. Vizsgálatunkban arra a megállapításra jutottunk, hogy a perifériás érbetegség jelentős mértékben járul hozzá a sebészi rekonstrukció sikertelenségéhez. Ennek a ténynek az alapja a gyengébb microvascularisatio és az alacsonyabb szöveti perfúzió. A vizsgálatban nem találtunk összefüggést egyéb rizikótényezók és a sebészi rekonstrukció sikertelensége között [11]. A radikális sebészi rekonstrukció, még sternumreszekció árán is, és a plasztikai sebészeti elvek alkalmazása a rekonstrukció során jobb eredményekhez vezetett a hagyományos szívsebészeti eljárásokkal szemben. A radikális sebészi rekonstrukció és az incisionalis negatív nyomású sebkezelés kombinációja jobb eredményeket és rövidebb kórházi tartózkodást eredményezett betegeinknél [12].

Anyagi támogatás: A közlemény megírása, illetve a kapcsolódó kutatómunka anyagi támogatásban nem részesült.

Szerzôi munkamegosztás: R. A.: A kutatási munka megtervezése, a cikk megírása. G. K.: Az adatok módszertani elemzése, részvétel a közlemény megírásában. F. M.: Az eredmények értékelése, részvétel a közlemény megírásá- ban. A. N.: Az eredmények értékelése, összefoglalása, részvétel a közlemény megírásában. V. Zs.: A közlemény lektorálása és részvétel a közlemény megírásában. A cikk végleges változatát valamennyi szerző elolvasta és jóváhagyta.

Érdekeltségek: A szerzőknek nincsenek érdekeltségeik.

\section{Irodalom}

[1] Sjögren J, Malmsjö M, Gustafsson R, et al. Poststernotomy mediastinitis: a review of conventional surgical treatments, vacuumassisted closure therapy and presentation of the Lund University Hospital mediastinitis algorithm. Eur J Cardiothorac Surg. 2006; 30: 898-905.

[2] Bratzler DW, Dellinger EP, Olsen KM, et al. Clinical practice guidelines for antimicrobial prophylaxis in surgery. Am J Health Syst Pharm. 2013; 70: 195-283.

[3] Garner JS, Jarvis WR, Emori TG, et al. CDC definitions for nosocomial infections, 1988. Am J Infect Control. 1988; 16: 128140.

[4] Pairolero PC, Arnold PG. Management of recalcitrant median sternotomy wounds. J Thorac Cardiovasc Surg. 1984; 88: 357364.

[5] Szerafin T, Péterffy Á. Early and long-term results of treatment for infected deep sternotomy wounds. [Szívmütétet követő mély sternotomiás sebfertőzések kezelésének korai és hosszú távú eredményei.] Orv Hetil. 2001; 142: 1321-1326. [Hungarian]

[6] Toumpoulis IK, Anagnostopoulos CE, Derose JJ, et al. The impact of deep sternal wound infection on long-term survival after coronary artery bypass grafting. Chest 2005; 127: 464-471.

[7] Rodriguez Centina Biefer H, Sündermann SH, Emmert MY, et al. Negative microbiological results are not mandatory in deep sternal wound infections before wound closure. Eur J Cardiothorac Surg. 2012; 42: 306-310.

[8] Simşek Yavuz S, Sensoy A, Ceken S, et al. Methicillin-resistant Staphylococcus aureus infection: an independent risk factor for mortality in patients with poststernotomy mediastinitis. Med Princ Pract. 2014; 23: 517-523.

[9] Filsoufi F, Castillo JG, Rahmanian PB, et al. Epidemiology of deep sternal wound infection in cardiac surgery. J Cardiothorac Vasc Anesth. 2009; 23: 488-494.

[10] Meszaros K, Fuehrer U, Grogg S, et al. Risk factors for sternal wound infection after open heart operations vary according to type of operation. Ann Thorac Surg. 2016; 101: 1418-1425.

[11] Morisak A, Hosono M, Sasaki Y, et al. Evaluation of risk factors for hospital mortality and current treatment for poststernotomy mediastinitis. Evaluation of risk factors for hospital mortality and current treatment for poststernotomy mediastinitis. Gen Thorac Cardiovasc Surg. 2011; 59: 261-267.

[12] Rashed A, Frenyo M, Gombocz K, et al. Incisional negative pressure wound therapy in reconstructive surgery of post-sternotomy mediastinitis. Int Wound J. 2017; 14: 180-183.

(Rashed Aref dr., Zalaegerszeg, Zrínyi M. u. 1., 8900 e-mail: aref.rashed.szv@zmkorhaz.hu) 